reduced egg production more drastically after hens were preconditioned with intermittent lighting than was the case following the $14 \mathrm{hr}$. of light a day of the maturation period.

One may conclude that dark treatment of Coturnix while almost completely preventing egg production during its application may serve to enhance afterwards the response of hens to light. In contrast, the intermittent light regime permits only sub-optimal productivity unless preceded by a dark period or perhaps other treatment; it has adverse effects on the subsequent ability of hens to lay in darkness, when compared to normal $14 \mathrm{hr}$. of light per day. These conclusions are in general agreement with results obtained for chickens ${ }^{2}$.

Hans Abplanalup

Department of Poultry Husbandry,

University of California, Davis, California.

'Hutchinson, J. C. D., Nature, 177, 795 (1956).

${ }^{2}$ Morris, T. R., and Fox, S., Nature, 182, 1522 (1958).

${ }^{3}$ Platt, C. S., Poultry Sci., 34, 1045 (1955).

'Sykes, A. H., J. Agric. Sci., 47, 429 (1956).

${ }^{5}$ Abplanalp, H., and Wilson, W. O., Ecology, 41, 580. Wilson, W. O., Abbott, U. K., and Abplanalp, H., Poultry Sci., 38,
1260 (1959).

\section{Presence of Blood Antigens in Fish Mucus and its Possible Parasitological Significance}

WE have recently shown in this laboratory that each species of fish appears to secrete its own specific mucus $^{1}$. The differences between mucus from various species can be detected by chromatographic methods. With closely related species, like Sebastes marinus I. and $S$. mentella Travin, several types of chromatographic technique may be required in order to detect any difference between the two forms of mueus ${ }^{2}$. At present we know very little about the nature of this species specificity of the mucus. Some of the chromatographically separable components fluoresce on exposure to ultra-violet radiation and some are ninhydrin-positive.

Fish serum proteins are, of course, species specific, and therefore we have used some specific anti-fish sera to test for the presence of serum protein components in body and gill mucus. The recently described cellulose acetate membrane immuno. diffusion method of Consden and $\mathrm{Kohn}^{3}$, which we have already shown can be used to distinguish between the closely related Sebastes species mentioned ${ }^{2}$, was used in this work.

Anti-bass (Labrax morone L.) serum $R 923$ was produced by injecting bass serum into a 2 -kgm. male albino rabbit by a course of subeutaneous injections according to the following procedure : A preliminary injection of $0.5 \mathrm{ml}$. bass serum was followed after a week by a second similar one with another three days later and a fourth two days later still. The rabbit was bled out under nembutal, a week after the last injection. The antiserum so produced gave a homologous titre of 1 in 12,000 and a photronreflectometer sigma tau value of 152 . Oudin ${ }^{4}$ and Ouchterlony ${ }^{5}$ immuno-diffusion studies showed that it contained at least six distinct antibodies to the homologous serum. Two of these antibodies reacted with components in Sebastes marinus serum and one reacted with cod (Gadus callarias L.) s9rum. No heterologous reaction with coalfish (Gadus virens L.) serum was

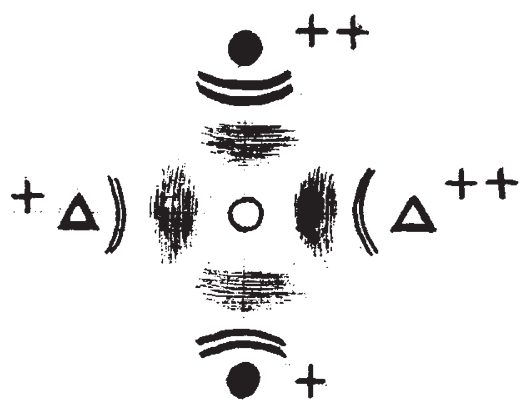

Fig. 1. Diagram of Consden-Kohn reactions between antibass serum $R 923(O)$ and bass mucus ( $O$ ). Upper and lower reactions are with body mucus and left and right reactions are with gill mucus $(\Delta)$. Plus signs indicate approximate quantities applied. The inner broad bands are nigrosine-positive, the outer lines of precipitation are both ponceau $S$ - and nigrosine-positive

detected. Further studies of bass blood are being reported elsewhere ${ }^{6}$.

When the anti-bass serum $R 923$ was treated with bass mucus using the Consden-Kohn cellulose acetate membrane technique it was found that three antigen antibody $(A n A b)$ reactions occurred (Fig. 1). The two outer $A n A b$ reactions were detectable by ponceau $S$ staining which produced fine clearcut lines of reaction. The more diffuse innermost zone of precipitation was not detectable with ponceau $S$, but required the use of nigrosine staining. It was also found, as can be seen in Fig. 1, that the gill and body mucus reacted somewhat differently. The reactions were stronger with body mucus than with gill mucus. This is perhaps surprising since gill mucus might be more likely to be contaminated with blood than body mucus. It should be pointed out that in the samples studied no contaminating blood was detected. Furthermore, the ponceau $S$-positive $A n A b$ reactions were well separated from each other whereas with gill mucus the two lines of precipitate, although discrete, were very close to each other. This would indicate that the relative concentrations of the two antigens involved differ in gill and body mucus.

Anticod serum $R 712$ available from previous work on intragenic relationships in the genus Gadus ${ }^{3}$ was used to study the body mucus of Gadus callarias. Only a single $A n A b$ reaction faintly ponceau $S$-positive was found. Subsequent staining with nigrosine gave no further reactions, but the ponceau $S$-positive band stained more strongly.

These results show that some of the serum protein antigens of fishes are also secreted in mucus. These species-specific antigens may be responsible, in part at least, for the ability of certain fish parasites to detect their specific hosts. Wright ${ }^{8}$ has pointed out that such parasites must detect their hosts by chemotactic methods, and the presence of species. specific serum proteins in the body mucus suggests a possible basis for this.

Further work is in progress.

Department of Zoology,

Fergus J. O'Rourke

University College, Cork.

${ }^{1}$ Barry, J. M., and O'Rourke, F. J., Nature, 184, 2039 (1959).

${ }^{2}$ O'Rourke, F. J., Copenhagen Redflsh Symposium, October 1959 (in the press).

${ }^{3}$ Consden, R., and Kohn, J., Nature, 188, 1512 (1959).

${ }^{4}$ Oudin, J., Ann. Inst. Pasteur, 75 (30-31), 109 (1948)

'Ouchterlony, O., Acta Path. et Microbiol. Scand., 26, 507 (1949).

${ }^{6}$ O'Rourke, F. J., Proc. Roy. Irish Acad., 61 B, 9, 167 (1960).

' O'Rourke. F. J., Nature, 183, 1192 (1959). ${ }^{8}$ Wright, C. A., Harris, R. H., and Claugher, D., Nature, 180, 1498 